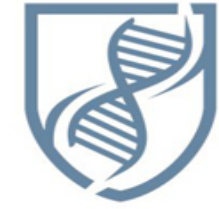

Journal of Bioscience and Applied Research

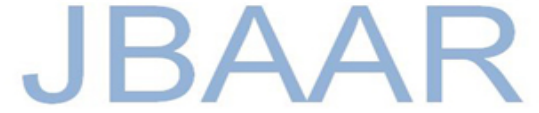

WWW.JBAAR.ORG

\title{
Environmental and physiological impacts of heavy metals on Nile tilapia (Oreochromis niloticus)
}

\author{
Bayomy, M. F. F ${ }^{1}$, Alne-na-ei, A. A. ${ }^{1}$, Gaber, H. S. ${ }^{2}$, Sayed, H. A ${ }^{3}$. Khairy D. ${ }^{2}$ \\ 1. Zoology Department, Faculty of Science, Menoufiya University,Shebin El-kom, Egypt \\ 2. Professor in Pollution laboratory, National Institute of Oceanography and Fisheries, El- Kanater El-Khairyia \\ 3. Organic Department, Central Laboratory for Environmental Quality Monitoring, El- Kanater El-Khairyia, Egypt
}

\begin{abstract}
The present study was conducted to investigate the distribution of selected metals $(\mathrm{Fe}, \mathrm{Zn}, \mathrm{Cd}, \mathrm{Pb}$, and $\mathrm{Cu}$ ) in tissues of Nile Tilapia (Oreochromis niloticus) grown along El- Khadrawia drain - Mubark industrial Zone. The tissues analyzed included muscle and liver. Results showed metal concentrations in water followed a richness of: $\mathrm{Fe}>$ $\mathrm{Zn}>\mathrm{Cu}>\mathrm{Pb}>\mathrm{Cd} \mathrm{mg/l}(\mathrm{p}<0.05)$ while $\mathrm{Fe}>\mathrm{Cu}>\mathrm{Zn}>\mathrm{Pb}$ $>\mathrm{Cd} \mathrm{mg} / \mathrm{Kg}$ dry wt. $(\mathrm{p}<0.05)$ in muscles and liver tissues in winter season. Metal levels in muscles follow the level: $\mathrm{Zn}>\mathrm{Fe}>\mathrm{Cu}>\mathrm{Pb}>\mathrm{Cd} \mathrm{mg} / \mathrm{Kg}$ dry wt. $(\mathrm{p}<0.05)$, while in liver they follow the level: $\mathrm{Fe}>\mathrm{Zn}>\mathrm{Cu}>\mathrm{Pb}>\mathrm{Cd} \mathrm{mg} / \mathrm{Kg}$ dry wt. $(\mathrm{p}<0.05)$ in summer season. The presence of heavy metals led to significant decrease in nucleic acids (DNA \& RNA) contents in liver tissue during summer season $(\mathrm{p}<0.05)$. So, the study showed that muscles of Nile Tilapia (Oreochromis niloticus) along El- Khadrawia drain are not safe from contamination with the metals investigated.
\end{abstract}

Keywords. Heavy metals, Nile tilapia, Liver, Muscle, DNA\&RNA

\section{Introduction}

Industrial development and increase of urbanization resulted in rapid increase of domestic and industrial wastewater which has intensify environmental pollution in different environmental compartments. Industrial and agricultural runoffs are considered the primary source of metal poisoning to fish and other aquatic animals in Egypt (Eissa et al., 2009 and Eissa et al., 2013). Fish are excellent organisms to study different effects of pollutants that cause genotoxicity through their aquatic environments (Koca et al., 2008). Heavy metals are non-biodegradable and persistent contaminants in the environment causing serious illness in fish, animals and human. Heavy metals after entering into aquatic environment accumulate in tissues and organs of fish that enter the food chain and elevate up to the highest level of consumers (Akan et al., 2009). They accumulated in aquatic organisms as an indicator of metal pollution (Karadede-Akin and Unlu, 2007) and affected them by changing the structural or biological functions of bio-molecules (Newman, 1998).

Prolonged exposure to water collected pollutants even in very low concentrations have been reported to induce morphological, histological and biochemical alterations in fish tissues, which may critically influence the quality and marketability of fishes (Kaoud and El-Dahshan, 2010). However, their persistence in the aquatic environment is surely related to the success of their immune system to counteract such impacts (Tort et al., 2003). It is also possible that environmental toxicants may increase the susceptibility of aquatic animals to various diseases by interfering with the normal functioning of their immune, reproductive and developmental processes (Eissa et al., 2013).

Nile Tilapia (Oreochromis niloticus) is a teleost fish with a worldwide distribution; therefore it is a good model for assessing the impacts of different environmental pollutants on aquatic ecosystems. A comparative study of five economically important taxa of tilapia showed that Nile Tilapia (Oreochromis niloticus) presents a God gifted strong immune system that maximizes their capability to tolerate biotic and abiotic types of stress (Eissa et al., 2012). Further, the natural surface feeder omnivorous non predator behavior of Nile tilapia might grant them another natural tool that minimizes their possibility of contracting numerous types of pollutants including biological/chemical forms when compared to bottom feeder fishes (Eissa et al., 2013).

Biomarkers such as DNA and RNA for water pollution are considered as early diagnostic tools for biological effect measurement and environmental quality assessment (Peakall, 1994). They are defined as a change in biological response that differs from molecular to organism level (Sanchez and Porcher, 2009). Therefore, this work aimed to measure heavy metals pollution rank in surface water and 
Nile Tilapia (Oreochromis niloticus) along El- Khadrawia drain - Mubark industrial Zone.

\section{Materials and Methods}

The industrial wastewater had many negative environmental impacts on El- Khadrawia drainage water, aquatic environment organisms and others environmental components. Many physiological determinations were carried out to evaluate negative impact of industrial wastewater on El- Khadrawia drainage water quality and biological quality on Nile tilapia, Oreochromis niloticus fish according standards quality.

\section{Study Area}

Mubarak Industrial Zone is located on the left ElKhadrawia drain (between 19,600 to $29 \mathrm{~km}$ of ElKhadrawia drain) at the intersection of the drain with the Cairo-Alexandria agricultural road as shown in Figure (1).

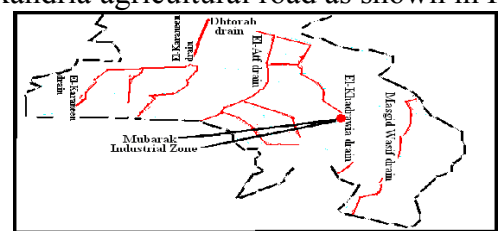

Fig. (1) Schematic Diagram for Mubarak Industrial Zone \& El-Khadrawia Drain

El-Khadrawia drain starts in the Menoufiya governorate passing centers including Brket El-Saba, Quesna, and ends in the Western Province center Zifta. The length of ElKhadrawia drain is $30 \mathrm{~km}$, and has an average disposition of the drain at the downstream $4.5 \mathrm{~m}^{3} / \mathrm{s}$ (about 400,000 $\mathrm{m}^{3} /$ day).

The El- Sahl canal in the east and El- Khadrawia canal in the west use large quantities of drain water with (El- Atf, Dhtorah and El- Karaneen) drains to mix with Abbasi Rayah water. This mixing compensate the shortage of irrigation water in periods of maximum agricultural needs through the station of Menoufiya pumps and estimated annual energy quantities confused 57 million $\mathrm{m}^{3}$.

\section{Sampling Program}

Water and Nile Tilapia fish (Oreochromis niloticus) samples were collected during one year. The selection of sites was chosen to represent non-polluted area as control sample and polluted area (Mubarak Industrial Zone) wastewater effect on El- Khadrawia drain as shown in Table (1).

Table (1). Environmental samples at ElKhadrawia Drain

\begin{tabular}{|c|c|l|}
\hline No. & Code & \multicolumn{1}{|c|}{ Sampling sites } \\
\hline $\mathbf{1}$ & $\mathbf{A}$ & $\begin{array}{l}\text { Non-polluted site, River Nile - El- } \\
\text { Kanater El- Khairyia }\end{array}$ \\
\hline $\mathbf{2}$ & $\mathbf{B}$ & $\begin{array}{l}\text { Drainage water before El-Khadrawia } \\
\text { drain with about 3 km. }\end{array}$ \\
\hline
\end{tabular}

\section{Water Samples}

Water samples were collected in triplicates in various containers specialized to uniform the nature of tested parameters according to international standard methods for examination of water and wastewater (APHA, 2005). Water samples were collected through winter 2012 and summer 2013 seasons from two sites that were: nonpolluted area - River Nile - El- Kanater El- Khairyia as control sample (A) and drainage water before ElKhadrawia drain with about $3 \mathrm{~km}$ (B) (Table 1) to evaluate water characterization chemically, bacteriology and toxic pollutants impacts on biological indicator Nile tilapia, Oreochromis niloticus.

For laboratory analyses, water samples were collected in stopper polyethylene plastic bottles. All collected and examined samples, for physical, chemical and bacteriological were stored in an iced cooler box and delivered immediately to the laboratory for analyses. The plastic bottles were cleaned by soaking in $10 \% \mathrm{HNO}_{3}$ and the procedural blanks of standard solutions were prepared under clean laboratory environment.

\section{Fish Samples}

Fish samples (Oreochromis niloticus) were collected from two sites and transported to laboratory for dissection and analysis (Table 1). Nile tilapia (non- polluted samples) ranged with average weight 118.45 to $330.3 \mathrm{~kg}$ and the length from 18.4 to $28.8 \mathrm{~cm}$. While fish samples collected from polluted area ranged with average weight from 70.06 to $246.94 \mathrm{~kg}$, and the length from 15.2 to $25.2 \mathrm{~cm}$. After dissection of fish, pieces from liver by digestion method of Oreochromis niloticus were taken and kept frozen at $-20{ }^{\circ} \mathrm{C}$ for heavy metals analysis.

Analytical Procedures

In situ, field parameters: Temperature ${ }^{\circ} \mathrm{C}, \mathrm{pH}$, Electric conductivity (E.C), Salinity, Total dissolved solids (TDS) and dissolved oxygen (D.O) were measured in situ using multi-probe system, model Hydralab-Surveyor, and remeasured in laboratory using the following bench top equipment's to ensure data accuracy (APHA, 2005).

Laboratory analysis (APHA, 2005): for laboratory analysis, all reagents were used for analytical grade and deionized water was used for all the prepared reagent solutions. Physico-chemical analyses including $\mathrm{pH}$ and EC were measured at $25^{\circ} \mathrm{C}$ using Info Lab meters, ammonium content using ammonia selective electrode ORION model 95-12 and checked by calorimetric techniques with formation of phenate. Also, turbidity (Turb) was measured by Turbidity meter with calibration solutions of $0.1,15$, and 100 NTU, Total dissolved solids (TDS) for filtrated water samples was determined gravimetrically at $105^{\circ} \mathrm{C}$.

Chemical analysis: Heavy metals $(\mathrm{Cd}, \mathrm{Cu}, \mathrm{Fe}, \mathrm{Pb}$, and $\mathrm{Zn}$ ), the samples were filtered by filtration system through membrane filter of pore size $0.45 \mu$ and acidified with nitric acid to $\mathrm{pH}$ and were measured by inductively coupled plasma-optical emission spectrometry (ICP-OES) and their recovery studies for the trace elements ranged between 99 and $102 \%$.

Fish samples: fish extracts for heavy metal determination were prepared by mixing $0.5 \mathrm{~g}$ of dry fish tissues (liver) for 24 hours at $70{ }^{\circ} \mathrm{C}$ with $6 \mathrm{ml}$ concentrated $65 \% \mathrm{HNO}_{3}$ and $1 \mathrm{ml} 30 \%$ hydrogen peroxide $\left(\mathrm{H}_{2} \mathrm{O}_{2}\right)$ for digestion using microwave digestion system (model Milestone, MLS-1200 mega, Germany) then ventilated for $5 \mathrm{~min}$ and filtrated to $100 \mathrm{ml}$ by using deionized water (DI). 
Three replications were performed for each fish sample. Nucleic acids contents DNA (deoxy ribonucleic acids) and RNA (ribonucleic acids) in liver were measured as described by Alexander et al., (1985).

Statistical analysis

Data were analyzed by analysis of variance using ANOVA Procedure, SAS System, Version 2004. All data is analyzed and presented as mean \pm standard error.

\section{Results}

The minimum value of temperature recorded in winter was $17.8{ }^{\circ} \mathrm{C}$ in the River Nile and the maximum value recorded in the summer was $32.63{ }^{\circ} \mathrm{C}$ in polluted site (B). Table (2) represented significant changes at $(\mathrm{P}<0.05)$ along polluted site $\mathrm{B}$ (drainage water before El-Khadrawia drain with about $3 \mathrm{~km}$ ) in the winter and summer seasons.

$\mathrm{pH}$ values in non-polluted (A) and polluted (B) sites varied from $7.18 \pm 0.012$ to $7.87 \pm 0.06$. The results recorded nonsignificant changes $(\mathrm{P}>0.05)$ at polluted site $(\mathrm{B})$ in the winter $(7.18 \pm 0.012)$ and summer $(7.46 \pm 0.08)$ as compared with non-polluted site (A).

E.C values in non-polluted (A) and polluted (B) sites varied from $0.361 \pm 0.002$ to $2.06 \pm 0.03$. The results recorded significant changes $(\mathrm{P}<0.05)$ at polluted site $(\mathrm{B})$ in the winter $(2.06 \pm 0.03)$ and summer $(1.418 \pm 0.006)$ as compared with non-polluted site (A). In similar, salinity values ranged from $0.19 \pm 0.011$ to $1.09 \pm 0.06$ in nonpolluted (A) and polluted (B) sites which noticed significant changes $(\mathrm{P}<0.05)$ at polluted site $(\mathrm{B})$ in winter and summer seasons in comparison with non-polluted site (A). Also, the results of TDS ranged from $232 \pm 0.55 \mathrm{mg} / 1$ to $1318 \pm 0.58 \mathrm{mg} / 1$ in non-polluted (A) and polluted (B) sites which showed highly significant increase $(\mathrm{P}<0.05)$ during winter and summer seasons as compared with nonpolluted site (A).

The minimum value of dissolved oxygen was $2.56 \pm 0.13$ $\mathrm{mg} / \mathrm{l}$ in winter and $2.98 \pm 0.03$ in summer for polluted site (B) while the maximum value of dissolved oxygen was $3.66 \pm 0.05$ in summer and $3.33 \pm 0.021 \mathrm{mg} / 1$ in winter for non-polluted site (A). The results clearly showed significant changes $(\mathrm{P}<0.05)$ at polluted site $(\mathrm{B})$ in winter and summer seasons as compared with non-polluted site (A).

Seasonal variations of turbidity in non-polluted (A) and polluted (B) sites varied from $0.14 \pm 0.01$ to $38 \pm 0.23$ which showed significant changes $(\mathrm{P}<0.05)$ in winter and summer seasons as compared with non-polluted site (A).

Table (2) showed that ammonia concentrations ranged from $0.95 \pm 0.005$ to $2.11 \pm 0.04 \mathrm{mg} / 1$ that were significantly different $(\mathrm{P}<0.05)$ for polluted site $(\mathrm{B})$ in winter season and non-significant in the summer season as compared with non-polluted site (A).
Table (2). Water Characterization of Non-polluted area and Polluted Area

\begin{tabular}{|c|c|c|c|c|}
\hline \multicolumn{5}{|c|}{ Environmental Samples } \\
\hline \multirow{2}{*}{$\begin{array}{l}\text { Physic- } \\
\text { Chemical } \\
\text { Measurement } \\
\text { s }\end{array}$} & \multicolumn{2}{|c|}{ Winter } & \multicolumn{2}{|c|}{ Summer } \\
\hline & $\overline{\mathbf{A}}$ & B & $\overline{\mathbf{A}}$ & $\bar{B}$ \\
\hline $\begin{array}{l}\text { Temperature } \\
{ }^{\circ} \mathrm{C}\end{array}$ & $17.8 \pm 0.03$ & $18.8 \pm 0.06^{*}$ & $30.43 \pm 0.12$ & $31.73 \pm 0.28^{*}$ \\
\hline $\mathrm{pH}$ & $7.87 \pm 0.06$ & $7.18 \pm 0.012$ & $7.58 \pm 0.017$ & $7.46 \pm 0.08$ \\
\hline E.C ds $/ \mathrm{m}$ & $0.434 \pm 0.001$ & $2.06 \pm 0.03^{*}$ & $0.361 \pm 0.002$ & $1.418 \pm 0.006^{*}$ \\
\hline Salinity & $0.22 \pm 0.006$ & $1.09 \pm 0.06^{*}$ & $0.19 \pm 0.011$ & $0.8 \pm 0.02^{*}$ \\
\hline D.O (mg/l) & $6.33 \pm 0.021$ & $2.56 \pm 0.13^{*}$ & $6.66 \pm 0.05$ & $2.98 \pm 0.03^{*}$ \\
\hline $\begin{array}{l}\text { TDS (mg/l) } \\
<1000\end{array}$ & $280 \pm 0.74$ & $1318 \pm 0.58^{*}$ & $232 \pm 0.55$ & $908 \pm 0.36$ * \\
\hline $\begin{array}{l}\begin{array}{l}\text { Turbidity } \\
\text { (NTU) }\end{array} \\
\end{array}$ & $7 \pm 1$ & $38 \pm 0.23$ * & $0.14 \pm 0.01$ & $6.8 \pm 0.49^{*}$ \\
\hline $\begin{array}{l}\text { Ammonia } \\
(\mathrm{mg} / \mathrm{l})\end{array}$ & $0.05 \pm 0.005$ & $2.11 \pm 0.04$ * & 0.01 & $0.26 \pm 0.003$ \\
\hline
\end{tabular}
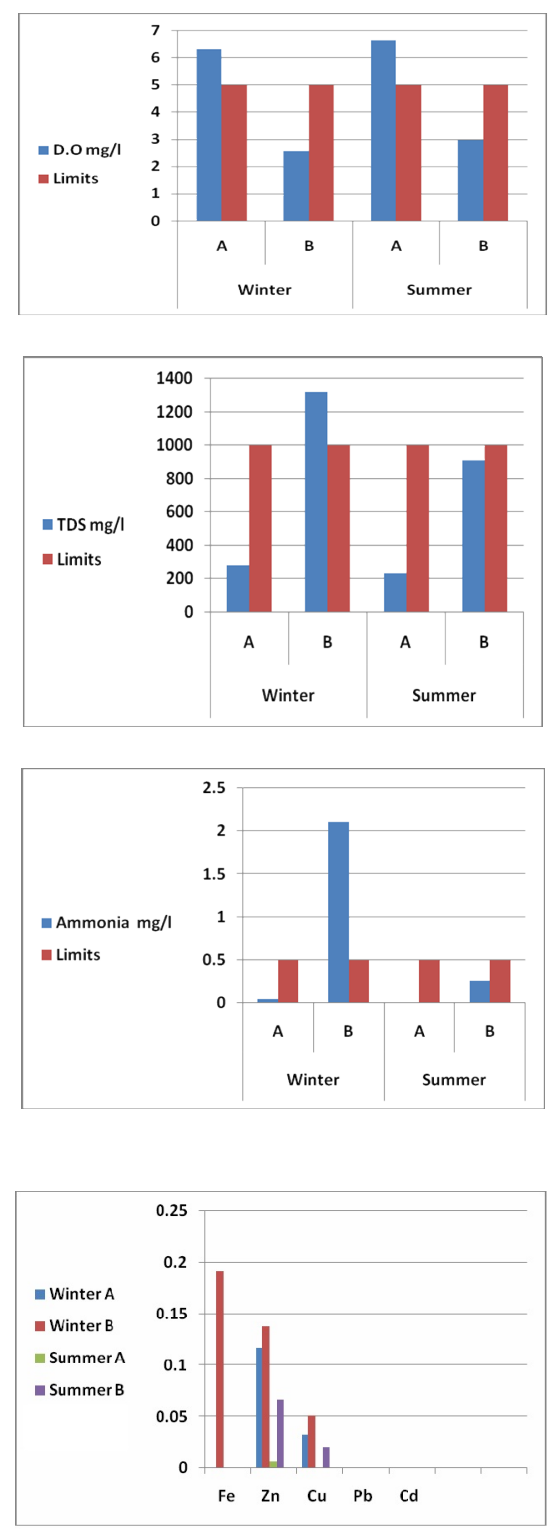
The values of iron concentrations in water samples of nonpolluted and polluted sites (A) and (B) were observed in table 3 . These results exhibited significant changes $(\mathrm{p}<$ 0.05 ) along polluted site (B) during winter season and $<0.01 \mathrm{mg} / 1$ in summer season in comparison with nonpolluted site (A).

Zinc concentrations in water samples of non-polluted and polluted sites A and B were observed in table 3 . It is apparent that zinc concentrations were significantly elevated $(\mathrm{p}<0.05)$ at polluted site $(\mathrm{B})$ during winter and summer seasons in comparison with non-polluted site (A).

Copper content in water samples of non-polluted and polluted sites $\mathrm{A}$ and $\mathrm{B}$ were observed in table 3 . From these results, it is apparent that copper concentrations were significantly elevated $(\mathrm{p}<0.05)$ at polluted site $(\mathrm{B})$ during winter and summer seasons in comparison with nonpolluted site (A).

Table 3 clarified lead and cadmium concentrations that were measured in water samples collected from nonpolluted and polluted sites (A and B). These results recorded under detection limits of ICP instruments $(<0.005$ and $<0.0005 \mathrm{mg} / 1$, respectively) during winter and summer seasons.

Table (3). Heavy Metals Concentrations (mg/l) in Water Samples along Non-polluted area and Polluted Area

\begin{tabular}{|c|c|c|c|c|}
\hline \multicolumn{5}{|c|}{ Environmental Samples } \\
\hline \multirow[t]{2}{*}{ Heavy Metals } & \multicolumn{2}{|c|}{ Winter } & \multicolumn{2}{|c|}{ Summer } \\
\hline & $\mathbf{A}$ & B & $\mathbf{A}$ & B \\
\hline Iron - Fe & $<0.01$ & $0.192 \pm 0.001^{*}$ & $<0.01$ & $<0.01$ \\
\hline Zinc-Zn & $0.117 \pm 0.0012$ & $0.138 \pm 0.001^{*}$ & $0.006 \pm 0.0006$ & $0.067 \pm 0.0015^{*}$ \\
\hline Copper-Cu & $0.033 \pm 0.0012$ & $0.051 \pm 0.0007$ & $<0.002$ & $0.02 \pm 0.001^{*}$ \\
\hline Lead- Pb & $<0.005$ & $<0.005$ & $<0.005$ & $<0.005$ \\
\hline Cadmium- Cd & $<0.0005$ & $<0.0005$ & $<0.0005$ & $<0.0005$ \\
\hline $\begin{array}{l}\text { Each value repr } \\
\text { Detection Limit }\end{array}$ & $\mathrm{n} \pm$ S.E. $\left({ }^{*}\right) \mathrm{P}<$ & compared with & lluted site (A) & \\
\hline
\end{tabular}
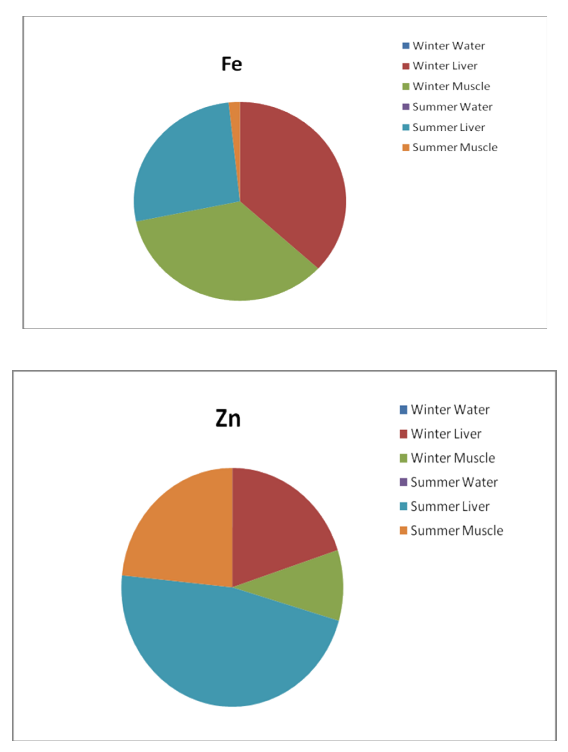
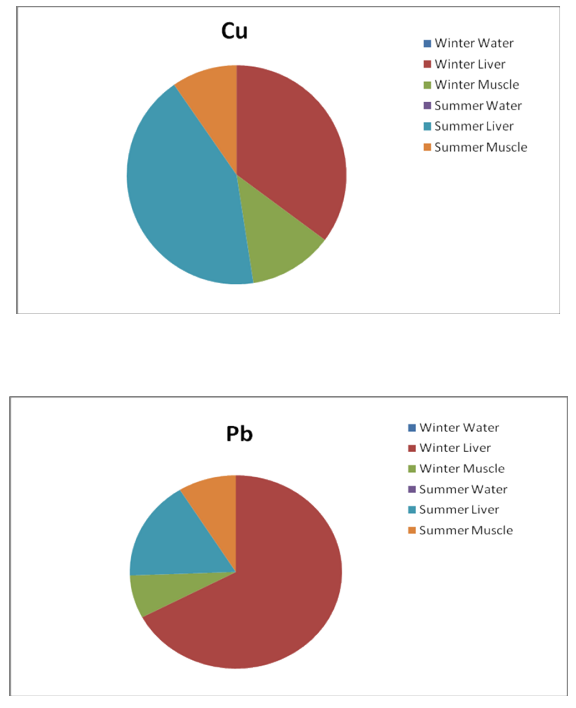

The seasonal variations in the concentrations of trace metals that were $\mathrm{Fe}, \mathrm{Zn}, \mathrm{Cu}, \mathrm{Pb}$ and $\mathrm{Cd}$ in different organs: liver and muscles fish of Oreochromis niloticus collected from the River Nile (non-polluted site - A) and ElKhadrawia drain (polluted site - B). All data of heavy metals accumulations in tissues (liver and muscles $-\mathrm{mg} / \mathrm{kg}$ dry wt.) recorded in table 4.

The values of iron concentrations in the muscles of fish samples Oreochromis niloticus showed that highly significant increase $(\mathrm{p}<0.05)$ at polluted site $(B)$ during winter and summer seasons in comparison with nonpolluted site (A). The iron concentrations in muscles reached the value of $61.908 \pm 0.51 \mathrm{mg} / \mathrm{kg}$ dry wt. in summer to $1264.52 \pm 0.51 \mathrm{mg} / \mathrm{kg}$ dry wt. in winter. While, the iron concentrations in the liver showed highly significant increase $(\mathrm{p}<0.05)$ at polluted site $(B)$ during the two seasons winter and summer in comparison with non-polluted site (A). The iron concentrations in liver reached the quantity of $961.197 \pm 0.55 \mathrm{mg} / \mathrm{kg}$ dry wt. in summer to $1332.53 \pm 0.5 \mathrm{mg} / \mathrm{kg}$ dry wt. in winter.

Zinc concentrations in the muscles of fish samples Oreochromis niloticus were highly significant increase at $(\mathrm{p}<0.05)$ in polluted site $(\mathrm{B})$ during winter and summer seasons in comparison with non-polluted site (A). Zinc concentrations in muscles reached the value of $55.469 \pm$ $1.18 \mathrm{mg} / \mathrm{kg}$ dry wt. in winter to $135.73 \pm 0.12 \mathrm{mg} / \mathrm{kg}$ dry wt. in summer; while, the concentrations of zinc in the liver of fish samples Oreochromis niloticus were highly significantly increased $(\mathrm{p}<0.05)$ at polluted site $(\mathrm{B})$ during winter and summer seasons in comparison with nonpolluted site (A). Zinc concentrations in liver reach the value of $115.62 \pm 0.31 \mathrm{mg} / \mathrm{kg}$ dry wt. in winter to $273.22 \pm$ $0.48 \mathrm{mg} / \mathrm{kg}$ dry wt. in summer.

Copper content in the muscles and liver of fish samples Oreochromis niloticus were highly significant increase $(\mathrm{p}<$ 0.05 ) at polluted site (B) during winter and summer seasons in comparison with non-polluted site (A). Copper concentrations in muscles reached the quantity of $54.207 \pm$ $0.4 \mathrm{mg} / \mathrm{kg}$ dry wt. in summer to $69.772 \pm 0.48 \mathrm{mg} / \mathrm{kg}$ dry 
wt. in winter season while copper concentrations in liver reached the value of $197.85 \pm 0.49 \mathrm{mg} / \mathrm{kg}$ dry wt. in winter to $241.057 \pm 1.13 \mathrm{mg} / \mathrm{kg}$ dry wt. in summer season.

The concentrations of lead in muscles and liver of fish samples Oreochromis niloticus showed highly significant changes $(\mathrm{P}<0.05)$ at polluted site $(\mathrm{B})$ during winter and summer in comparison with non-polluted site (A). Lead concentrations in muscles reached the value of $0.968 \pm 0.02$ $\mathrm{mg} / \mathrm{kg}$ dry wt. in winter to $1.2 \pm 0.04 \mathrm{mg} / \mathrm{kg}$ dry wt. in summer season while lead concentrations in liver reached the value of $2.259 \pm 0.03 \mathrm{mg} / \mathrm{kg}$ dry wt. in summer to 9.102 $\pm 0.1 \mathrm{mg} / \mathrm{kg}$ dry wt. in winter season.

Cadmium content in the muscles and liver of fish samples Oreochromis niloticus recorded $<0.0005 \mathrm{mg} / \mathrm{kg}$ dry wt in non-polluted site (A) and polluted site (B) during winter and summer seasons.

Table (4). Heavy metals concentrations (mg/kg dry wt.) in fish tissues along non-polluted area and polluted area

\begin{tabular}{|c|c|c|c|c|c|c|c|c|}
\hline \multirow{3}{*}{$\begin{array}{l}\text { Heavy } \\
\text { Metals }\end{array}$} & \multirow{2}{*}{\multicolumn{4}{|c|}{$\begin{array}{l}\text { Winter } \\
\text { inte }\end{array}$}} & \multicolumn{4}{|c|}{ Summer } \\
\hline & & & & & L & Muscle & Liver & Muscle \\
\hline & & & Liver & Muscle & Liver & & & \\
\hline $\mathrm{Fe}$ & $\begin{array}{l}22.47 \\
\pm 0.22\end{array}$ & $\begin{array}{l}13.053 \\
\pm 03 \\
\pm 03\end{array}$ & $\begin{array}{l}1332.53 \\
\pm 05 *\end{array}$ & $\begin{array}{l}1264.52 \\
\pm 0.5 \%\end{array}$ & $\begin{array}{l}17.646 \\
\pm 0.5 \\
0.5\end{array}$ & $\begin{array}{l}14.231 \\
\pm 0.41\end{array}$ & $\begin{array}{l}961.197 \\
00.55 *\end{array}$ & $\begin{array}{ll}61.908 \\
\pm 0.5 *^{*}\end{array}$ \\
\hline $\mathrm{zn}_{\mathbf{n}}$ & 34.56 & 25.564 & 115.62 & 55.469 & $\frac{16.583}{36.583}$ & 9.727 & 273.22 & 135.73 \\
\hline$C$ & $\frac{ \pm 0.42}{27.814}$ & $\frac{ \pm 0.33}{22.562}$ & $\frac{ \pm 0.31 *}{197.85}$ & $\begin{array}{l} \pm 1.1 .18 * \\
69.772\end{array}$ & $\frac{ \pm 0.47}{20.828}$ & $\frac{ \pm 0.37}{5.444}$ & $\frac{ \pm 0.48 *}{241.057}$ & $\frac{ \pm 0.12 *}{54.207}$ \\
\hline & \pm 0.51 & \pm 0.49 & \pm 0.49 * & $\pm 0.48^{*}$ & \pm 0.51 & \pm 0.04 & $\pm 1.13 *$ & $\pm 0.4^{*}$ \\
\hline $\mathrm{Pb}$ & $\begin{array}{c}0.425 \\
\pm\end{array}$ & 0.268 & $\begin{array}{l}9.102 \\
\pm 0.1 *\end{array}$ & $\begin{array}{c}0.968 \\
\pm 0.02 *\end{array}$ & 0.297 & 0.035 & $\begin{array}{c}2.259 \\
\pm 0.03 \text { * }\end{array}$ & $\begin{array}{c}1.2 \\
\pm 0.04 *\end{array}$ \\
\hline $\mathrm{Cd}$ & ${ }_{05}^{<0.00}$ & $<0.0005$ & $<0.0005$ & $<0.0005$ & $<0.0005$ & $<0.0005$ & $<0.0005$ & $<0.0005$ \\
\hline
\end{tabular}
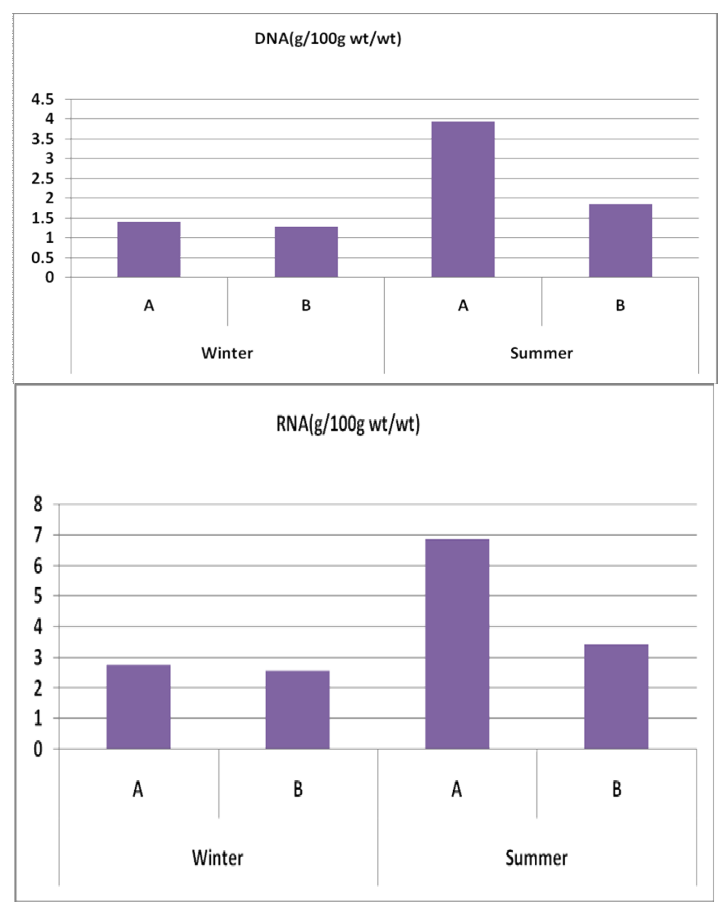

Water pollution in El- Khadrawia drain caused variation of Nucleic acids content in the liver for Nile Tilapia, Oreochromis niloticus fish. The results clarified DNA (deoxy ribonucleic acids) was significant decrease changes $(\mathrm{P}<0.05)$ during summer at polluted site $(\mathrm{B})$ in comparison with non-polluted site (A). DNA (deoxy ribonucleic acids) concentrations $(\mathrm{g} / 100 \mathrm{~g} \mathrm{wt} / \mathrm{wt})$ in liver reached of $1.285 \pm$
$0.11 \mathrm{~g} / 100 \mathrm{~g} \mathrm{wt} / \mathrm{wt}$ in winter to $1.844 \pm 0.05$ in summer as comparison with non-polluted site (A)

It was apparent that RNA (ribonucleic acids) content showed significant decrease $(\mathrm{P}<0.05)$ during the summer in comparison with non-polluted site (A). The maximum decrease RNA (ribonucleic acids) concentrations (g/100g $\mathrm{wt} / \mathrm{wt}$ ) in liver reached of $2.582 \pm 0.22 \mathrm{~g} / 100 \mathrm{~g} \mathrm{wt} / \mathrm{wt}$ in winter to $3.429 \pm 0.25 \mathrm{~g} / 100 \mathrm{~g} \mathrm{wt} / \mathrm{wt}$ in summer as comparison with non-polluted site (A).

Table (5). Nucleic acids content in Liver tissue of fish in non-polluted and polluted Area

\begin{tabular}{|l|c|c|c|c|}
\hline \multicolumn{5}{|c|}{ Environmental Samples } \\
\hline \multirow{2}{*}{$\begin{array}{c}\text { Nucleic } \\
\text { acids } \\
\text { content }\end{array}$} & Winter & \multicolumn{2}{c|}{ Summer } \\
\cline { 2 - 5 } & & & A & B \\
\hline DNA (g/100g & 1.409 & 1.285 & 3.921 & $1.844 \pm$ \\
wt/wt) & \pm 0.08 & \pm 0.11 & \pm 0.44 & $0.05 *$ \\
\hline RNA (g/100g & 2.749 & 2.582 & 6.884 & $3.429 \pm$ \\
wt/wt) & \pm 0.24 & \pm 0.22 & \pm 0.38 & $0.25 *$ \\
\hline $\begin{array}{l}\text { Each value represents Mean } \pm \text { S.E, } \mathrm{n}=10 .\left(^{*}\right) \mathrm{P}<0.05 \text { compared } \\
\text { with non-polluted site (A) }\end{array}$ \\
\hline
\end{tabular}

\section{Discussion}

The results of trace elements in water and fish samples were compared with Egyptian Environmental Law 48Decision 92/2013 and FAO 1983 to evaluate certain food additives and contaminates.

Soluble species of heavy metals are dangerous to fish in natural water that affected fish tissues by external and internal factors. High metal concentrations in aquatic environment caused high accumulation metals in Nile Tilipia Oreochromis niloticus. Metal concentrations in water of polluted site (B) as compared with non-polluted site (A) followed a richness of: $\mathrm{Fe}>\mathrm{Zn}>\mathrm{Cu}>\mathrm{Pb}>\mathrm{Cd} \mathrm{mg} / 1$ while $\mathrm{Fe}>\mathrm{Cu}>\mathrm{Zn}>\mathrm{Pb}>\mathrm{Cd} \mathrm{mg} / \mathrm{Kg}$ dry wt. in muscles and liver tissues in winter season. Metal levels in muscles follow the level: $\mathrm{Zn}>\mathrm{Fe}>\mathrm{Cu}>\mathrm{Pb}>\mathrm{Cd} \mathrm{mg} / \mathrm{Kg}$ dry wt., while in liver follow the level: $\mathrm{Fe}>\mathrm{Zn}>\mathrm{Cu}>\mathrm{Pb}>\mathrm{Cd} \mathrm{mg/Kg}$ dry wt. in summer season.

The presence of heavy metals in El- Khadrawia drain was mainly of allochthonous origin of industrial wastewater, drainage water and sewage wastewater. The obtained mean values of all heavy metals in water not exceeded Egyptian Environmental Law 48-Decision 92/2013 in winter and summer seasons. While, all metals in fish tissues (muscles and liver) exceeded FAO, 1983 limits except $\mathrm{Cd}(<0.0005$ $\mathrm{mg} / \mathrm{kg}$ dry wt).

The higher heavy metals concentrations were found in liver and muscles of Nile Tilipia Oreochromis niloticus fish tissues more than the aquatic environment (El- Khadrawia drain). Nile Tilipia Oreochromis niloticus fish adsorb soluble heavy metals causing accumulation in liver and muscles with highly significant quantities, thus showing caused toxicological effects (Osman et al., 2009). 
Trace elements in fish tissues were always higher than water that confirmed with Chale, 2002, Abumourad et al., 2014 and Riani, 2015 may be due to the variety of and occurrences on fish body and other aquatic biota, including the regular diffusion, bio-magnifications, and bioconcentration (Boisson et al., 2003). The lowest concentrations of metals were found in muscle tissues than liver (Yacoub and Gad, 2012); this may due to the little blood supply to the muscular tissues (Kalkan, et al., 2015) and related to lower metabolic activities of muscle. The lowest concentrations of metals were found in muscle tissues than liver and brain; this may due to the little blood supply to the muscular tissues (Kalkan, et al., 2015) and related to lower metabolic activities of muscle. Liver is the main centre for various metabolisms where detoxification and drug metabolism take place which makes it greatly vulnerable to damage by toxic substances (Čelechovská et al., 2007).

The presence of heavy metals in El- Khadrawia drain (site B) led to significant decrease in nucleic acids (DNA \& RNA) contents of Nile Tilipia Oreochromis niloticus fish tissues (liver) during summer season in comparison to nonpolluted (site A). The data were similar to those of Yousafzai and Shakoori, (2011) for freshwater fish, Tor putitora samples caught from River Kabul and Habib and Abou Shehatta, (2013) for catfish, Clarias gariepinus of Sites Kafr El-Bateekh and Talkha. Significant decrease in nucleic acids contents may be due to proteolysis and increased catabolism under toxicant stress (Remia et al., 2008) or may be due to its utilization to mitigate the energy demand when the fish are under stress (Venkataramana et al., 2006). DNA damage of Nile tilapia Oreochromis niloticus fish occurred due to exposure to agricultural and industrial wastewater (Lima et al., 2006 and Farag et al., 2006).

\section{Conclusion}

The present study was done through the research plan of the National Institute of Oceanography and Fisheries, Cairo, Egypt and National Water Research Center (NWRC) - Center Laboratory Environmental Monitoring Quality (CLEQM). In order to gain information's about the environmental status of industrial wastewater quality that discharges in drains and River Nile streams and their negative impacts on aquatic organisms, especially fresh water Nile Tilapia, Oreochromis niloticus.

\section{References}

Abumourad, I.M.K.; Abbas, W.T.; Authman, M.M.N. and Girgis, S.M. (2014) : Environmental Impact of Heavy Metal Pollution on Metallothionein Expression in Tilapia nilotica. Egypt. J. Res. Pharma. Biol. \& Chem. Sci., 5(2): 998.

Akan, J.C.; Abdulrahman, F.I.; Sopido, O.A. and Akandu, P.I. (2009): Bioaccumulation of some heavy metals of six fresh water fishes caught from Lake Chad in Doron Buhari, Maiduguri, Borno State, Nigeria. J. Appli. Sci. and Sanitation, 4 (2): 103-114.

APHA (2005): Standard Methods for the Examination of Water and Wastewater, $21^{\text {st }}$ ed. American public Health Association. New York.
Boisson, F.; Cotret, O.; Teyssi, J.L.; El- Barradei, M. and Fowler, S.W. (2003): Relative importance of dissolved and food pathways for lead contamination in shrimp. Marin. Poll. Bulletin, 46: 1549 - 1557

Čelechovská, O.; Svobodová, Z.; Žlábek, V. and Macharáčková, B. (2007): Distribution of Metals in Tissues of the Common Carp (Cyprinus carpio L.). Acta., Vet., Brno., 76: S93-S100.

Chale, F.M.M. (2002): Trace Metal Concentration in Water, Sediments and Fish Tissue from the Lake Tanganyika. Sci. Total Environ., 299: 115-121.

Egyptian Governmental Law No. 48/ 1982- Decision 92 (2013): The implementer regulations for Law 48/ 1982, 92/ 2013 regarding the protection of the River Nile and water ways from pollution . Map Periodical Bull., 21-30.

Eissa, A.E.; Moustafa, M.; El-Husseiny, I.N.; Saeid, S.; Saleh, O. and Borhan, T. (2009): Identification of some skeletal deformities in some freshwater teleost raised Egypt. aquacul. Chemo., 77: 419-425.

Eissa, A.E.; Hussein, H.A. and Zaki, M.M. (2012): Detection of Avian Influenza (H5N1) in some fish and shellfish from different aquatic habitats across some Egyptian provinces. J. Life Sci., 9: 2702-2712.

Eissa, A.E.; Tharwat, N.A. and Zaki, M.M. (2013): Field assessment of the mid winter mass kills of trophic fishes at Mariotteya stream, Egypt: chemical and biological pollution synergistic model. Chemo., 90: 1061-1068.

Farag, A.M.; May,T.; Marty, G.D.; Easton, M.; Harper, D.D.; Little, E.E. and Cleveland, L. (2006): The effect of chronic chromium exposure on the health of Chinook salmon, Oncorhynchus tshawytscha. Aquat. Toxicol., 76(3-4): 246- 257.

Food and Agricultural Organization (FAO) (1983): Compilation of Legal Limits for Hazardous Substances in Fish and Fishery Products Food and Agriculture Organization Fishery Circular No 464: Rome, Italy: 5-100.

Girón-Pérez, M.I.; Santerre, A.; Gonzalez-Jaime, F.; Casas-Solis, J.; Hern ndez-Coronado, M.; PeregrinaSandoval, J.; Takemura, A. and Zaitseva, G. (2007): Immunotoxicity and hepatic function evaluation in Nile tilapia (Oreochromis niloticus) exposed to diazinon. Fish and Shellfish Immunology, 23: 760-769.

Habib, S.A. and Abou Shehatta, A.M. (2013): Effect of Heavy Metals Pollution on Protein Biosynthesis in Catfish Journal of Water Resource and Protection Vol. 5(5):555562

Kalkan, H.; Sisman, T. and Kiliç, D. (2015): Assessment of Heavy Metal Bioaccumulation in Some Tissues of Leuciscus Cephalus from Karasu River, Erzurum-Turkey. Austin. J. Environ. Toxicol., Vol. 1(1): 1004-1007

Kaoud, H.A. and El-Dahshan, A.R. (2010): Bioaccumulation and histopathological alterations of the heavy metals in Oreochromis niloticus fish. Natur. Sci., 8: 147-156.

Karadede-Akin, H. and Unlu, E. (2007): Heavy metals concentrations in water, sediment, Fish and some benthic organisms from Trigris River, Turkey. Environ. Monitor. Assess., 131: 323-337. 
Koca, S.; Koca, Y.B.; Yildiz, S. and Gürcü, B. (2008): Genotoxic and histopathological effects of water pollution on two fish species, Barbus capito pectoralis and Chondrostoma nasus in the Büyük Menderes River, Turkey. Trace Element Res., 122: 276-291.

Lima, P.L.; Benassi, J.C.; Pedrosa, R.C.; Dal Magro, J.; Oliveira, T.B. and Wilhelm, F.D. (2006): Time-course variations of DNA damage and biomarkers of oxidative stress in tilapia (Oreochromis niloticus) exposed to effluents from a swine industry. Arch. Environ. Contam. Toxicol., 50(1): 23-30.

Newman, M.C. (1998): Fundamentals of Ecotoxicology. Ann Arbor Press, Chelsea, USA, PP.; 2539.

Osman, A. and Werner, K. (2009): Water quality and heavy metal monitoring in water, sediments, and tissues of the African Catfish Clarias gariepinus (Burchell 1822) from the River Nile. Egypt. J. Environ. Protect., 1: 389-400

Peakall, D.W., (1994): Biomarkers: the way forward in environmental assessment. Toxicol. \& Ecotoxicol., News 1, $55 / 60$.

Remia, K.M.; Logaswamy, S.; Logankumar, K. and Rajmohan, D. (2008): Effect of an insecticide (Monocrotophos) on some biochemical constituents of the fish Tilipia Mossambica. Poll. Res., 27(3): 523-526.
Riani, E. (2015):The Effect of Heavy Metals on Tissue Damage in Different Organs of Goldfish Cultivated in Floating Fish Net in Cirata Reservoir, Indonesia. J. Res., Paripex- Indian, Vol. 4(2), P.;132-136.

Sanchez, W. and Porcher, J. M. (2009): Fish biomarkers for environmental monitoring within the Water Farmework Directive of the European Union. Trac -Trends in Analytical Chemistry, 28(2), P.; 150-158.

Tort, L., Balasch, J.C. and Mackenzie, S. (2003): Fish immune system. A crossroads between innate and adaptive responses. Immuno., 22: 277-286.

Venkatramana Sandhya, G.V.; Rani, P.N. and Moorthy, P.S. (2006): Impact of Malathion on the biochemical parameters of gobiid fish, Glossogobius giuris (Ham). J. Environ. Biol., 27(1): 119-122.

Yousafzai, A.M., and Shakoori, A.R. (2011) : Hepatic Responses of A Freshwater Fish Against Aquatic Pollution. Pakistan. J. Zool., Vol. 43(2): 209-221. 